supply is to be obtained. Here, indeed, may be a matter in which the National Register might be utilized with advantage and a scheme of co-operation or control in making the appointments may well be essential, especially when it is remembered that welfare work is assuming increasing importance in the sphere of civil defence. The necessity for an examination and comb-out in the women's services if we are to make full use of trained personnel was well shown in the examples cited by Miss Ward in her speech in the debate on Production, Supply and Man-power in the House of Commons on January 21.

Once again the report makes plain the inherent possibilities which may emerge from the complica. tions caused by this redistribution of population, and its references to these possibilities are among the most interesting parts of the report. Country life is proving of the greatest value to the bodies and minds of town children, and it may be hoped that the new understanding of the country, and surprising interest in all rural pursuits may be shared by their parents sufficiently to help to secure a more balanced national economy. The new amenities and departures in social welfare now being established in the reception areas may have their own influence in arresting the drift from the country to the town if the nation can continue such experiments after the war.

If such hopes are to be realized, there must, indeed, be a fuller understanding by the countryman or woman and the townsman or woman of each other's sentiments, habits and outlook, the absence of which did much to wreck the evacuation scheme in 1939 . While the Committee seems surprisingly satisfied with the success of the subsequent evacuation, it is clear that a large number of the evacuees have settled down happily in the reception areas, and that in the great majority of cases the experiment is succeeding, particularly with the unaccompanied children. The extent of the migration is sufficiently indicated by the 25 per cent increase in the population of the reception areas visited by the Committee during the first year of the War, exclusive of the large number of service personnel stationed in them, in contrast with a decline of more than 10 per cent in the year before the War. Two-thirds of this increase has been due to unorganized evacuation - the arrival, without notice, of more than a million people, many of the priority groups, who have since been billeted and in the face of these figures the amount of confusion and friction, both of which are diminishing, is surprisingly small.

The mingling of town and country, the engendering of mutual understanding, of goodwill and good behaviour on both sides, encouraged as they have been by the ordeals of the last nine months, may well prove a solid asset when the need for evacuation is past. The suggestions and recommendations of the Committee, based on the experience gained, are designed to diminish the strains or friction set up and to promote fuller understanding as well as morale. They are not, indeed, novel. Many of the remedies have been frequently urged unofficially before--for example, in the reports of the evacuation committee of the Association of Architects, Surveyors and Technical Assistants, and of the Department of Social Science of the University of Liverpool.

Their official reiteration is none the less useful on that account, and has already had effect in regard to co-ordination in billeting and in the steps already taken to stop the dispatch of official parties to areas believed to be saturated, a position which has been reached already in certain districts more readily accessible from London.

The recommendations in regard to the immediate adaptation of emergency premises earmarked for the treatment of epidemics and the greater provision of premises for infectious diseases, for the wider extension of the district medical service and for the extension of the voluntary hospitals contributory scheme, where possible, to evacuees in the reception areas, are equally important. So, too, is the recommendation that careful watch should be kept on watersupply, sanitation and sewage disposal, where the influx of population has proved their inadequacy. Still more significant, however, is the reliance placed by the Committee on the regional machinery for giving effect to its recommendations. A wider use of regional powers originally, instead of giving large and drastic powers to the local authorities, which they were reluctant to use, might have avoided much unnecessary friction. The whole trend of the report in this respect is an answer to the severest criticism of evacuation contained in the Evacuation Survey report to the Fabian Society, edited by $R$. Padley and Margaret Cole, and it may well prove that adoption of the Committee's recommendations will give a further impulse to regionalism in Great Britain, and the handling. of social problems on regional rather than local lines.

\title{
GRAVITY ANOMALIES AND THE EARTH'S FIGURE
}

$\mathrm{T}$ HE literature on this subject is so voluminous and scattered, in many cases in periodicals that are not easily accessible, that a publication such as that by B. L. Gulatee*, which provides an introduction to the fundamental problems, with special reference to investigations developed in recent years and to practical applications, is likely to be welcomed by a wide circle of readers. Chapter i deals with the various gravity formulæ and gives brief proofs. The practical derivation of the empirical formulæ is reviewed in Chapter ii. Gravity observations and arc measurements show that a triaxial

* Gravity Anomalies and the Figure of the Earth. By B. L. Gulatee. Pp. viii $+116+10$ flgs. (Survey of India, Prof. Pap. 30, Dehra Dun, Pp. viii $+116+10$ figs.
1940.) R.3 or 5 s. net. ellipsoid fits the geoid better than a spheroid; but it is pointed out that the ellipticity of the geoidal equator is not yet indisputably proved. The observations have been made only on limited portions of the globe, and until more gravity determinations are made in suitable areas the question will remain open.

Chapter iii gives an account of Clairaut's, Darwin's and de Sitter's theories of the figure of the earth. Certain objections are pointed out and reference is made to the more recent work of Jeffreys, in which he draws inferences from the moon's motion and so avoids the necessity of making any hypothesis about the internal state of the earth. In Chapter iv, which deals with gravity anomalies, a useful summary is given illustrating the application of such anomalies 
to the elucidation of the geological structure and history of those regions where they have been specially studied.

No matter what hypothesis of compensation is adopted, considerable anomalies persist in certain regions, examples of which are Peninsular India, the Ferghana Basin, Japan, the Dutch East Indies, the Caucasus, the Caribbean Sea, many oceanic deeps and islands, and the African Rift Valleys.

Regions of large positive anomalies, being areas of overload, should be expected to be continuously sinking. A notable exception is provided by the island of Cyprus, which has risen, despite its positive anomalies. Such evidence, like that of the 'negative belt' around the Dutch East Indies, provides evidence of phenomena going on inside or below the earth's crust. Another application of gravity anomalies is the derivation of the form of the geoid ; this is discussed in Chapter v. Finally, in Chapter vi, the various types of reference surfaces are defined and it is shown that it is necessary to distinguish a triangulation reference spheroid from one based on gravity measurements.

For convenience the diagrams have been placed all together at the end of the book on two double pages, so that they can be opened and seen clear of the text. A list of symbols is given for easy reference. If a second edition be called for, as seems likely, it might usefully be provided with an index.

\section{FORTHCOMING EVENTS}

[Meeting marked with an asterisk is open to the public.]

\section{Monday, March 3}

Royal Geographical Society (at Kensington Gore, London, S.W.7), at 5 p.m.-Dr. N. A. Mackintosh: "The Last Cruise of R.R.S. Discovery II".

\section{Tuesday, March 4}

ROYal Institution (at 21 Albemarle Street, London, W.1), at 2.30 p.m.-Prof. H. A. R. Gibb : "Egypt".*

\section{Thursday, March 6}

LinNean Society of London (at Burlington House, Piccadilly, London, W.1), at 3 p.m.-General Meeting.

\section{Saturday, March 8}

Geologists' Association (at the Imperial College of Science and Technology, Prince Consort Road, London, S.W.7), at 3 p.m.-Annual General Meeting. Mr. W. P. D. Stebbing: "The Early Use of Subsoils in Farming, and the Farmer and his Instructors before William Smith".

\section{APPOINTMENTS VACANT}

AppuICATIONs are invited for the following appointments on or before the dates mentioned:

Chief Assistant for Higher Eddcation-The Director of Education, Town Hall, Bradford (endorsed 'Chief Assistant for Higher Education') (March 7)

Lecturer in Mechanical Engineering-The Principal, College of Technology and Commerce, Leicester (March 8).

HEADMASTER of the Sunderland Junior Technical School-The Director of Education, Education Offices, 15 John Street, Sunderland (March 10).

Civil Enginearing Assistant to the River Ouse (Yorks.) Catchment Board-The Clerk to the River Ouse Catchment Board, 7 Langcliffe Avenue, Harrogate (endorsed 'Engineering Assistant') (March 10). REGISTRAR of University College, Southampton-The Registrar, University College, Southampton (March 18).
Head of THE School of Textines-The Principal, College of Technology and Commerce, Leicester (March 24).

TenNent Professor of OPhThalmologY-The Acting Secretary of University Court, University, Glasgow (May 1).

Graduate in Engineming SubJects-The Principal, Dursley Technical Institute, Dursley, Glos.

LeCTURER IN THE MECHANICAI ENgINeERING Department-The Clerk to the Governors, Technical College, Chesterfleld.

Assistant Engrneer for the Malayan Public Works Service-The Crown Agents for the Colonies, 4 Millbank, London, S.W.1 (quoting M/9306).

\section{REPORTS AND OTHER PUBLICATIONS}

(not included in the monthly Books Supplement)

\section{Great Britain and Ireland}

John Innes Leaflet No. 4: The Fertility Rules in Fruit Planting. Pp. 8. (London: John Innes Horticultural Institution.) 6d. [16 Hull Museum Publications. No. 207: Excavations at Elmswell East Yorkshire, 1938. By Philip Corder. Pp. $62+4$ plates. No. 208 Saxon Relics from Barton, Lines., and from Elloughton, E. Yorks. By Thomas Sheppard. Pp. 26. No. 209: A Panel of Celtic Ornament from Elmswell, East Yorkshire. By Philip Corder and C. F. C. Hawkes. Pp. $22+4$ plates. No. 210 : Early Tramcars and Record of Additions. By Thomas Sheppard. Pp. 38, No. 211: Yorkshire Neolithic ImpleScientific Proceedings of the Royal Dublin Society. Vol. 22 (N.S.) No. 31: Salmon of the Ballisodare River, 1: History of the BalNo. 31: Salmon of the Ballisodare River, 1: History of the Bal-


Age and Growth. By Arthur E. J. Went. Pp. 327-344. 2s. 6d. Age and Growth. By Arthur E. J. Went. Pp. 327-344. $2 s .6 d$. (Dublin: Hodges, Figgis and Co., Ltd. ; London: Williams and
Norgate, Ltd.) Imperial Bureau of Soil Science. Technical Communication No. 40 The Rothamsted Field Experiments on the Growth of Wheat. By Sir E. J. Russell and D. J. Watson. Pp. xi $+164+3$ plates. (Har penden: Imperial Bureau of Soil Science.) $78.6 d$.

Manchester Museum : University of Manchester. Museum Publication 117 : Report of the Museum Committee for the Year 1939-40. Pp. 28. (Manchester: Manchester Museum.) 6d. net. [29] The Research Association of British Rubber Manufacturers. Pp. 16. (Croydon: Research Association of British Rubber Manufac-
turers.)

\section{Other Countries}

Southern Rhodesia Geological Survey. Short Keport No. 33 Geological Report on the Manesi Gold Belt. By B. Lightfoot. Pp: $7+1$ map. (Salisbury : Geological Survey.)

Dominion of Canada: Department of Transport, Air Services Branch: Division of Meteorological Services of Canada. Canadiail Polar Year Expeditions, 1932-33. Meteorology : Cape Hope's Advance, Chesterfleld Inlet, Coppermine, Meanook. Vol. 1. Pp. xvi+
$443+46$ plates. (Ottawa : Government Printer.)

Tanganyjka Territory: Department of Lands and Mines, Geological Division. Bulletin No. 14: Mica in Tanganyika. By Dr. G. J. Williams and A. F. Skerl. Pp. $52+7$ plates. (Dar es Salaam : Govern-
ment Printer.) 38 .

Indian Forest Records (New Series). Entomology, Vol. 6, No. 4. Entomological Investigations on the Spike Disease of Sandal (35) Further Studies on the Spike Disease of Sandal. By Rao Sahib S. Rangaswami and A. L. Griffith. Pp. vi $+85-196+12$ plates. (New Delhi : Manager of Publications.) $4 \cdot 4$ rupees ; $6 s .9 d$. [2412 Union of South Africa : Department of Mines : Geological Survey. The Geology of the Country around Potchefstroom and Klerksdorp. An Explanation of Sheet No. 61 (Potchefstroom) by Dr. Louis T. Nel, Dr. F. C. Truter and Dr. J. Willemse, incorporating previous Observations by Dr. E. T. Mellor. Pp. 132. (Pretoria : Government Printer.) 58., including Map.

161

U.S. Department of Agriculture. Technical Bulletin No. 728 : Parasites of the Oriental Fruit Moth in Japan and Chosen and their Introduction into the United States. By G. J. Haeussler. Pp. 62. (Washington, D.C.: Government Printing Office.) 10 cents. ${ }_{[201}$ Smithsonian Miscellaneous Collections. Vol. 99, No. 15: Evidence of Early Indian Occupancy near the Peaks of Otter, Bedford County, Virginia. By David I. Bushnell, Jr. (Publication 3601.) Pp. ii $+14+5$ plates. Vol. 99, No. 16: New Fossil Lizards from the Upper Cretaceous

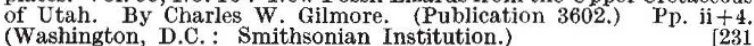
(Washington, D.C.: Smithsonian Institution.) [231 Journal of the Faculty of Science, Imperial University of Tokyo, Part 2: Utber die Strukt, Astronomy, Physics, Chemistry. Vol. 4 vom Primzahlgrad $l$. Von Eizi -Kaba 3:- Potany. Yol. 5, Part 4. The Genus Hosta. 1.10 yen. Section Pp. 317-426. 3.60 yen. (Tokyo: Maruzen Co., Ltd.) [231 Department of Science and Agriculture, Jamaica. Bulletin No. 19 : Fertilizer Investigations with the Gros Michel Banana. By H. H. Croucher and W. K. Mitchell. Pp. $30+10$ plates. 6d. Bulletin No: 22 : Report on the Coconut Growing Areas of Jamaica. By F. M. Bain. Pp. 12. 6d. Bulletin No. 23: A Survey of the Yields of Sugar Cane in Jamaica, 1938-1939. Report by R. F. Innes. Pp. 40. 6d. Bulletin No. 24: A Survey of the Yields of Sugar Cane in Jamaica, 1937-1938. Report by H. H. Croucher. Pp. 30. 6d.
Government Printing Office.)
[291 